\title{
Book Review: Genocide: New Perspectives on Its Causes, Courses and Consequences
}

Linda F. Burghardt

Holocaust Memorial \& Tolerance Center of Nassau County NY

Follow this and additional works at: https://digitalcommons.usf.edu/gsp

\section{Recommended Citation}

Burghardt, Linda F. (2018) "Book Review: Genocide: New Perspectives on Its Causes, Courses and Consequences," Genocide Studies and Prevention: An International Journal: Vol. 12: Iss. 1: 101-102. DOI:

https://doi.org/10.5038/1911-9933.12.1.1578

Available at: https://digitalcommons.usf.edu/gsp/vol12/iss1/10

This Book Review is brought to you for free and open access by the Open Access Journals at Digital Commons @ University of South Florida. It has been accepted for inclusion in Genocide Studies and Prevention: An International Journal by an authorized editor of Digital Commons @ University of South Florida. For more information, please contact digitalcommons@usf.edu. 


\title{
Book Review: Genocide: New Perspectives on its Causes, Courses and Consequences
}

\author{
Linda F. Burghardt \\ Holocaust Memorial \& Tolerance Center of Nassau County, NY \\ Nassau County, NY, USA
}

Genocide: New Perspectives on its Causes, Courses and Consequences

Uğur Ümit Ünğor, editor

Amsterdam University Press, Amsterdam, 2016

286 Pages; Price: \$110 Hardcover

Reviewed by Linda F. Burghardt

Holocaust Memorial \& Tolerance Center of Nassau County, NY

Genocide has been called the "crime of crimes," and with good reason, as the actions and belief systems that underlie its manifestation encompass collective violence on a scale virtually all people find inconceivable. Yet the scholars who contributed their insights and analyses to Uğur Ümit Ünğor's remarkable book have not only conceived and named the causes and effects of genocide, they have explained them to us in ways that touch the very nature of the mass atrocities themselves and expose the inner workings of the minds of those who perpetrated them.

The twelve outstanding essays in this collection each deal with the fundamental facts in their own way, offering both original thinking and deftly created arguments to bring us a deep understanding of the genocidal events and processes as a whole and the specifics of particular instances of it. The contributors represent a wide range of international scholarship, with associations with universities in Amsterdam, Bucharest, Ghent, Utrecht and Ottawa, among others.

The book is part of the prestigious NIOD Studies on War, Holocaust and Genocide series, published by the Amsterdam University Press. The series focuses on the impact of war, the Holocaust, and genocide on 20th century societies. It aims for diverse disciplinary perspectives, set within a global context, and encompasses a wide range of historical approaches. The NIOD is the national center for documentation of World War II in the Netherlands.

Informing the book throughout its pages is an exploration of the dark side of human nature, the part of all people that often acts in ambivalence and ambiguity when it comes to the surface, often under circumstances in which our own inhibitions fail to counter strong communal forces of aggression. We are shown how our darker side is fragile and vulnerable, that crises can bring out behavior in which empathy and identification with others fail to materialize, and that hate may grow when serious polarization between groups and society is encouraged by what may be experienced as hypnotic illusions or delusions. Can this part of human nature be tamed? Yes, imply several of the essays. Can it be eliminated? Here the implication is a strong no.

So what is to be done? The scholarly tone of the multiplicity of answers is set by the editor in his opening essay, in which he discusses how genocide, horrific though it is, continues to endure in our modern age. Ügür Ümit Ungör, associate professor in the Department of History at Utrecht University and at the NIOD Institute for War, Holocaust, and Genocide Studies in Amsterdam, uses genocidal events in Syria as an object lesson, describing in clear language how protests there spread across the country and ultimately crossed the threshold of violence. He then deftly pulls apart the threads to show us the central dynamic operating within the system, carefully and impressively illustrating some of the individual thinking within the collective acts.

No one kills in a historical or cultural vacuum, he explains, then leading gracefully into the themes that illuminate the chapters in the book, such as struggles over truth, justice, and memory. We learn that in the $20^{\text {th }}$ century alone, about 40 to 60 million people were systematically murdered within the complex process of genocide, and already the $21^{\text {st }}$ century has seen episodes of genocide in Darfur, Myanmar, Congo, and Sri Lanka, among others. The essays Dr. Ünğor assembled here ask why genocide continues, why it is difficult to stop, why so many societies that are so varied in political structure, culture, and level of technology all fall victim to this vicious process. Ultimately, we gain fresh understanding through the answers the individual authors posit. 
The book is divided into three distinct sections: the causes of genocide, the courses it takes, and its ultimate consequences, just as the title promises. Within each part are three articles that weave together specific views and examples. Genocidal locations discussed in the book range from Romania and Serbia to the Philippines, from Kampuchea in Cambodia to Holocaust Germany, from Sarajevo to Rwanda and Sierra Leone. Under the direction of the article authors, the reader easily makes the leap from state deviancy to paranoid purges to sexual violence and comes to understand the role of memory and education and transitional justice and history.

Several essays prove this postulate. In Part II of the book, Courses of Genocide, for example, the essay by Franziska Karpinski and Elysia Ruvinsky, both of whom have degrees from the University of Amsterdam, stands out in its searing and original analysis of sexual violence in Holocaust Germany. Together the two scholars pursue an understanding of the relationship between gender, law, and ideology under the Nazis by illustrating how violence, death and sex were not only closely related but also seemingly interdependent. While it was illegal to rape, it was legal to murder during the Nazi genocide, and the essay explores the types of sexual violence that occurred in and seeks to explicate their causes.

The essay by Christophe Busch of the Memorial Museum Center on Holocaust and Human Rights in Belgium highlights Part I of the book, Causes of Genocide, by explaining some of the deeper issues in the way ordinary human beings are brought to commit extraordinary systematic evil. He maintains that collective violence does not occur by chance, but rather by conscious design. Nevertheless, he maintains that each person has an individual responsibility for-and a choice about-his or her actions. And while he posits that all people have the capacity for both good and evil, being involved with forces that execute what he calls demonic crimes changes people; however, and inevitably leads them further down the path, albeit by often tiny steps, toward genocidal acts they will one day commit themselves.

Consequences of Genocide, Part III, contains a particularly cogent article by Suzanne Hoeksema, who was educated at Upsalla University in Sweden, dealing with serious attempts at the re-education of the perpetrators of the genocide in Rwanda and tackles the question of whether or not they can be fully rehabilitated. Can divisive ideologies be eliminated in the minds of genocidal criminals? She cites the power of redefining ethnicity and creating a new view of politics as two successful attempts at answers, and studies how reshaping national narratives can have a positive effect on creating harmony and balance between the perpetrators' image of society and the socio-political reality, all along pointing out the dangers that are always at play in the fragile lives of those trying to reimagine their nation.

The book, while directed toward academics, will also appeal to a broader range of scholarsthose who work in think tanks or create government policies, for example-as it is well-organized and accessible and free of arcane language.

Clearly, the scope of the book is huge, and best read and digested in small chunks. Much of it is deeply painful, not because it is sensationalized, but simply because the subject matter and the depth of the analysis brings us to the conclusion that genocide will never end. By the time we reach the epilogue, deftly written by Philip Spencer of Kingston University in London, we are ready for a coming to terms, a sense that the trauma experienced by the victims might be overcome, and that the crimes of the perpetrators might be admitted. Yet Spencer is realistic, and though he has framed his arguments in a most elegant and thorough way, and his conclusions are inescapable, our hearts nevertheless cry out our desire for a more positive version of our own flawed selves. 